\title{
PENGOLAHAN MOTIF YANG TERINSPIRASI DARI TENUN GRINGSING WAYANG KEBO DENGAN TEKNIK DIGITAL PRINTING PADA PRODUK WOMENSWEAR
}

\author{
Made Devi Savitri Wirawan, Morinta Rosandini \\ (devisavitriwir@gmail.com, Morintarosandini@telkomuniversity.ac.id) \\ Program Studi Kriya \\ Fakultas Industri Kreatif \\ Telkom University \\ Jalan Telekomunikasi, No. 1, Kabupaten Bandung, Indonesia
}

\begin{abstract}
ABSTRAK
Tenun Gringsing Wayang Kebo yang merupakan kain bertuah yang ditenun oleh masyarakat Desa Tenganan Pagringsingan dan dikenal sebagai kain tenun ikat ganda dengan motif yang penuh dengan makna filosofis. Dengan adanya potensi visual dari motif Tenun Gringsing Wayang Kebo untuk membuat inovasi komposisi motif baru menggunakan ornamen yang terinspirasi dari motif Tenun Gringsing Wayang Kebo. Metode yang digunakan dalam penelitian ini adalah metode kualitatif yaitu studi pustaka yang berkaitan dengan filosofi dan analisis ornamen motif Wayang Kebo dan eksperimen penyusunan kembali ornamen motif dengan melakukan stilasi bentuk ornamen dan komposisi yang terinspirasi dari Tenun Gringsing Wayang Kebo. Hasil eksperimen tersebut kemudian diaplikasikan dengan teknik rekalatar yaitu cetak digital dan hiasan manik-manik di atas material polyester dan organza untuk kemudian dapat diterapkan kedalam produk fesyen. Hasil eksperimen stilasi bentuk dan komposisi motif dengan pola motif simetris dan teknik pengulangan setengah langkah, diterapkan dengan warna lembut sebagai wujud inovasi yang lebih moderen. Penelitian ini menghasilkan koleksi dengan penggayaan yang lebih moderen dan kemudian diaplikasikan pada desain womenswear ready-to- wear. Pembuatan motif ini bertujuan untuk mengangkat budaya lokal menjadi sebuah potensi pengembangan desain motif baru serta menjadi referensi desain pada busana etnik moderen untuk para desainer, pelaku bisnis, dan masyarakat luas
\end{abstract}

Kata Kunci : Digital Imaging, Motif, Tenun Gringsing Wayang Kebo, Womenswear.

\begin{abstract}
Tenun Gringsing Wayang Kebo is a sacred textile which is weaved by the villagers of Desa Tenganan Pagringsingan and known as the double-tied weaved textile with full of philosophical motif. With the visual potential from Tenun Gringsing Wayang Kebo to form an innovation of new composisition motif using the ornament that inspired by motif Tenun Gringsing Wayang Kebo. The qualitative method applied for this research by doing the study literature of philosophy and ornament analysis from the Wayang Kebo pattern and a re-arrange the pattern ornament experiment with doing a stilation motif shape and composition that inspired by Tenun Gringsing Wayang Kebo. The result of the experiment applied using surface design technique which is digital printing and beading embellishment with polyester and organza material that can applied into a fashion product. The result of shape stilation and motif composition experiment with symmetrical motif pattern and half-drop repetition technique, applied into the soft color pallete as a form of modern innovation. The result of this research is the collection with a modern style and later, will be applied
\end{abstract}


into a womenswear ready-to-wear design. The purpose from creating new motif is to lift the local culture to become a developed new motif potential also become a modern ethnic fashion design reference for designers, business people and society

Keywords: Digital Imaging; Motif; Tenun Gringsing Wayang Kebo; Womenswear

\section{PENDAHULUAN}

Bali adalah salah satu daerah dengan beragam kebudayaan yang berkembang disetiap daerah. Bertahun-tahun masyarakat Bali mewariskan dan mengkreasikan budaya yang beraneka ragam sesuai dengan kepercayaan masyarakat adatnya. Budaya tersebut seperti upacara keagamaan, tradisi sembahyang sampai seni patung, lukis, musik, wastra, dan tari (Salain, 2017). Jika melihat sisi kekayaan budaya yang ada di Bali, Desa Tenganan Pagringsingan adalah salah satu desa dari sekian banyak desa yang sangat dikenal akan kebudayaannya. Desa Tenganan Pagringsingan merupakan salah satu desa yang dihuni oleh keturunan penduduk suku asli Bali yang disebut Bali Aga dan terletak di Kecamatan Manggis, Kabupaten Karangasem, Provinsi Bali (Lodra, 2015). Saat ini Desa Tenganan merupakan salah satu desa tujuan wisata karena kebudayaan yang masih kental dengan kehidupan penduduk ini sehingga banyak wisatawan yang tertarik untuk mengunjungi dan melihat langsung budaya yang masih bertahan (Setyadi, 2007). Dari banyaknya kebudayaan yang masih ada di Desa Tenganan, salah satu budaya yang bertahan dan memiliki nilai tinggi adalah wastra atau kain tradisionalnya yaitu Tenun Gringsing. Tenun ini dibuat dengan teknik ikat ganda serta menggunakan bahan dan pewarna alam dalam pembuatannya (Widiawati \& Rosandini, 2012). Selain itu kain ini dipercaya oleh masyarakat sebagai wastra bertuah yang dapat menyembuhkan penyakit serta menolak bahaya dan digunakan dalam prosesi sakral atau upacara keagamaan (Kartiwa, 2007). Motif Wayang Kebo pada merupakan salah satu motif Tenun Gringsing yang rumit dan memiliki komposisi kompleks yang membuat motif ini langka di pasaran. Motif ini memiliki 3 pembagian yaitu utama, tengan dan tepi (Mudra \& Putriani, 2018). Motif yang ada dalam masing-masing pembagiannyapun memiliki filosofi yang saling terikat dengan Desa Tenganan Pagringsingan. 
Di sisi lain perkembangaan wastra yang ada di Bali, saat ini Bali juga sudah memiliki perkembangan industri tekstil dan mode sendiri yang maju, hal ini bisa terlihat dari sudah mulai bermunculannya brand lokal yang meramaikan pasar industri fesyen dengan produk khas mereka untuk menarik minat masyarakat sampai wisatawan. Dari brand lokal yang ada, terlihat adanya beberapa local brand Bali yang membuat beberapa produk siap pakai dengan mengaplikasikan motif yang terinspirasi dari kain tradisional Indonesia. Tetapi dari bermunculannya brand lokal Bali dengan produk khasnya, masih jarang ditemukan local brand yang menggunakan inspirasi kain asli Bali pada produk ready-to-wear womenswear yang dipasarkan, padahal Bali sendiri kaya akan kain yang khas, salah satunya ada kain Tenun Gringsing. Seperti yang sudah disebutkan sebelumnya, kain ini memiliki beberapa kelebihan dari kain asal Bali lainnya, yaitu pada keunikan pada unsur motif yang mewujudkan karakter Bali dan susunan motif yang tersusun penuh serta detail pada setiap sisinya. Pada penelitian sebelumnya sudah banyak dilakukan pengolahan motif

yang terinspirasi dari elemen budaya lokal seperti seperti penelitian oleh (Andini \& Rosandini, 2018) yang mengolah ornamen pada ukiran Taman Sari Keraton Yogyakarta menjadi inspirasi bentuk untuk busana womenswear. Pada penelitian tersebut aplikasi motif dilakukan dengan menggunakan proses digital dalam pembuatannya. Oleh karena itu, pengolahan motif dari arftefak lokal lainnya seperti kain Tenun Geringsing Wayang Kebo dapat dilakukan dalam upaya memanfaatkan potensi visualnya agar dapat diolah menjadi bentuk baru yang lebih inovatif dan memiliki unsur lebih modern serta dapat diterima oleh satu target market tertentu. Dibutuhkan teknik pengolahan yang berbeda dari pembuatan motif sebelumnya, pada penelitian ini pengolahan motif ini akan dilakukan dengan teknik digital imaging pada software pengolah gambar yaitu Adobe photoshop dan diaplikasikan diatas kain dengan teknik digital printing, untuk memenuhi kebutuhan produksi masal pada produk womenswear. Hal tersebut secara tidak langsung akan membantu pengenalan motif Wayang Kebo didalam Tenun Gringsing ke tengahtengah masyarakat sehingga dapat membuat masyarakat sadar dengan keberadaan dari Tenun Gringsing khususnya Tenun Gringsing Wayang Kebo.

\section{METODE PENELITIAN}


Metode yang digunakan dalam penelitian ini menggunakan metode kualitatif, diantaranya adalah eksperimen, obervasi, wawancara dan studi literatur.

1. Observasi dan wawancara digunakan sebagai metode untuk mengumpulkan data yang valid tentang keberadaan Tenun Gringsing Wayang Kebo. Observasi dan wawancara dilakukan langsung ke Desa Tenganan Pagringsingan dan mewawancarai Pak Made Kodok sebagai salah satu penduduk asli Desa Tenganan Pagringsingan.

2. Studi literatur merupakan data yang didapat dari buku dan jurnal ilmiah lalu digunakan sebagai data untuk menganalisis filosofi dan bentuk dari ornamen yang terdapat pada Tenun Gringsing Wayang kebo sebelum nantinya ornamen ini akan diolah dengan Teknik Digital Imaging.

3. Selain studi literatur, eksperimen merupakan salah satu metode yang digunakan dalam penelitian ini. Eksperimen dilakukan dengan mengolah gambar digital dari Tenun Gringsing Wayang Kebo menjadi berbagai macam variasi motif.

\section{HASIL}

Langkah pembuatan inovasi motif baru ini pun dimulai dari proses tracing dan stilasi pada ornamen motif Wayang Kebo, lalu pergantian teknik ke teknik olah gambar digital dengan cara menyeleksi gambar dan memotongnya menjadikan sebuah gambar objek digital baru. Setelah dilakukan pemotongan objek, objek tersebut akan dikomposisikan dan langkah selanjutnya yaitu eksperimen terhadap test print serta eksplorasi teknik beading menggunakan kain yang memiliki motif. Setelah semua eksplorasi dipilih, kemudian masuk ke tahap perancangan produk dan produksi produk.

Analisis motif Tenun Gringsing Wayang Kebo hasil dari penelitian ini adalah berupa analisis prinsip, unsur rupa serta penggayaan yang ada pada motif Tenun Gringsing Wayang 
Tabel 1. Tabel analisis ornamen motif Tenun Gringsing Wayang Kebo

\begin{tabular}{|c|c|}
\hline Pembagian motif & Analisis motif \\
\hline 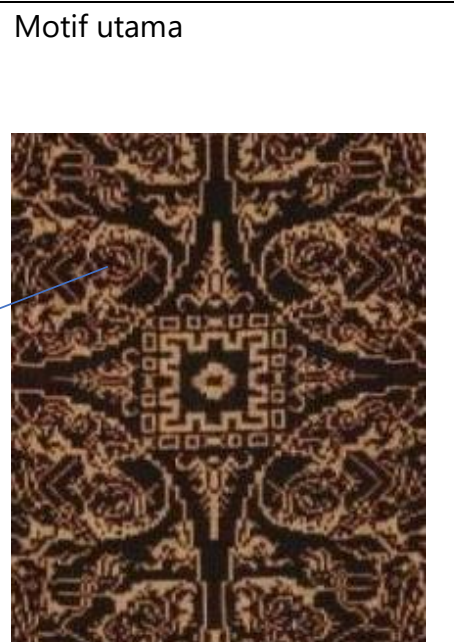 & $\begin{array}{l}\text { - Motif utama atau main pattern memiliki komposisi center dengan } \\
\text { penggayaan teknik pencerminan atas bawah dan kanan kiri } \\
\text { menjadikan motif central ini simetris. } \\
\text { - Pada motif central, objek digambar tidak memenuhi seluruh } \\
\text { permukaan sehingga tersisa beberapa ruang tanpa motif } \\
\text { - Pada main pattern ini warna yang digunakan hanya dua, yaitu } \\
\text { warna untuk motif dan latar belakang. Motif menggunakan warna } \\
\text { putih kekuningan, sedangkan untuk warna latar belakang berwarna } \\
\text { coklat kehitaman. } \\
\text { - Karena kain ini merupakan kain tenun garis pada kain ini tegas dan } \\
\text { kaku karena pewarnaan sesuai dengan warna benang. Berbanding } \\
\text { terbalik dengan batik yang pewarnaannya menggunaan perintang } \\
\text { malam yang digambar dengan canting } \\
\text { - Pada main pattern ini bentuk objek yang ada di dalamnya digambar } \\
\text { dengan kaku menggunakan sudut sudut bukan garis melengkung }\end{array}$ \\
\hline 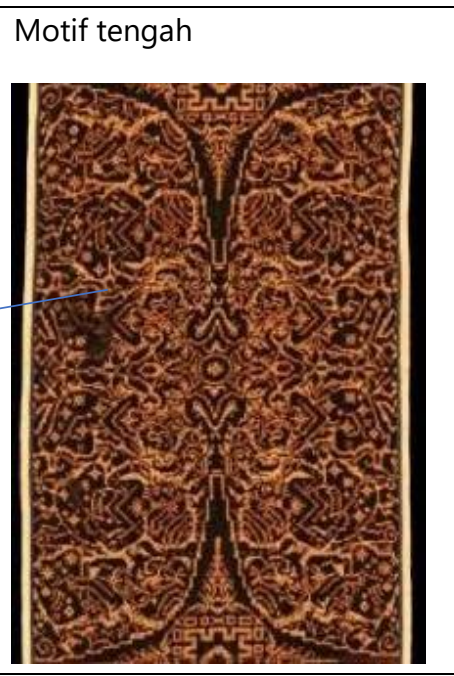 & $\begin{array}{l}\text { - Motif tengah atau middle pattern memiliki penggayaan teknik } \\
\text { pencerminan atas bawah dan kanan kiri menjadikan motif tengah } \\
\text { ini simetris. } \\
\text { - Motif ini dibuat dengan gambar penuh tanpa meninggalkan } \\
\text { rongga tanpa motif pada kain } \\
\text { - Pada middle pattern ini warna yang digunakan hanya dua, yaitu } \\
\text { warna untuk motif dan latar belakang. Motif menggunakan warna } \\
\text { putih kekuningan, sedangkan untuk warna latar belakang } \\
\text { berwarna coklat kehitaman. } \\
\text { - Karena ini merupakan kain tenun jadi pembuatan motif yang ada } \\
\text { di atas kain merupakan hasil dari pewarnaan benang. Garis pada } \\
\text { motif terlihat seperti mozaik (pada bagian objek yang } \\
\text { menggunakan garis melengkung) dan garis tegas (pada objek } \\
\text { yang menggunakan garis lurus) } \\
\text { - Berbeda dengan motif utama, di dalam motif tengah terdapat } \\
\text { beberapa objek yang dibuat dengan garis melengkung }\end{array}$ \\
\hline 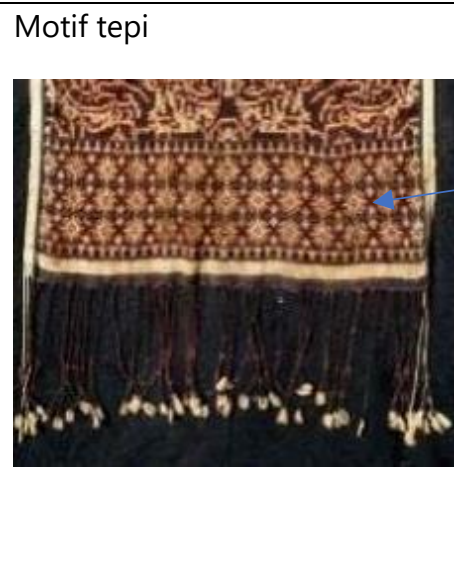 & $\begin{array}{l}\text { - Motif tepi atau edge pattern memiliki penggayan dengan teknik } \\
\text { square repeat atau pengulangan satu langkah. } \\
\text { - Motif ini dibuat dengan gambar penuh tanpa meninggalkan } \\
\text { rongga tanpa motif pada kain } \\
\text { - Pada edge pattern ini warna yang digunakan hanya dua, yaitu } \\
\text { warna untuk motif dan latar belakang. Motif menggunakan warna } \\
\text { putih kekuningan, sedangkan untuk warna latar belakang berwarna } \\
\text { coklat kehitaman. } \\
\text { - Karena kain ini merupakan kain tenun garis pada kain ini tegas dan } \\
\text { kaku karena pewarnaan sesuai dengan warna benang. } \\
\text { - Pada motif tepi objek dibentuk dengan garis tegas dan sudut sudut } \\
\text { tanpa menggunakan garis melengkung. } \\
\text { - Penggayaan pada motif tepi adalah geometris dimana gambar } \\
\text { objek yang ada didalam motif ini merupakan objek geometris. }\end{array}$ \\
\hline
\end{tabular}

(sumber : dokumentasi pribadi, 2019) 
Kesimpulan: Dari analisis yang dilakukan terhadap ornamen-ornamen yang terdapat pada motif Wayang Kebo dapat disimpulkan bahwa unsur garis serta titik banyak digunakan dalam beberapa ornamen.

tabel 2. Tabel filosofi ornamen motif Wayang Kebo

\begin{tabular}{|c|c|c|c|c|}
\hline No & $\begin{array}{l}\text { Jenis } \\
\text { Motif }\end{array}$ & Gambar & Motif & Filosofi \\
\hline 1 & $\begin{array}{l}\text { Motif } \\
\text { Utama } \\
\text { (Main } \\
\text { pattern) }\end{array}$ & & & $\begin{array}{l}\text { motif ini menjadi motif pusat dari motif } \\
\text { wayang kebo itu sendiri. Motif ini } \\
\text { memiliki tiga arti. Yaitu arah mata angin, } \\
\text { pintu masuk dari desa tenganan itu } \\
\text { sendiri serta elemen elemen kehidupan. } \\
\text { Seperti } 4 \text { arah mata angin yaitu utara, } \\
\text { selatan, timur dan barat, Desa Tenganan } \\
\text { Juga memiliki } 4 \text { pintu masuk. elemen } \\
\text { kehidupan yang dimaksud adalah Tri } \\
\text { Hita Karana dimana menyebutkan } \\
\text { tentang keseimbangan hubungan } \\
\text { manusia. Baik hubungan manusia } \\
\text { dengan sesama, manusia dengan } \\
\text { lingkungan, serta manusia dengan tuhan }\end{array}$ \\
\hline & & & 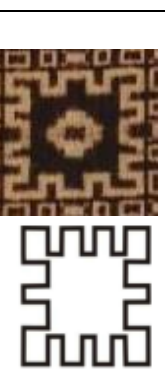 & $\begin{array}{l}\text { Swastika merupakan salah satu simbol } \\
\text { sakral pada Agama Hindu. Swastika pada } \\
\text { motif ini menunjukan kemuliaan serta } \\
\text { kesakralan tenun ini. Beberapa juga }\end{array}$ \\
\hline
\end{tabular}




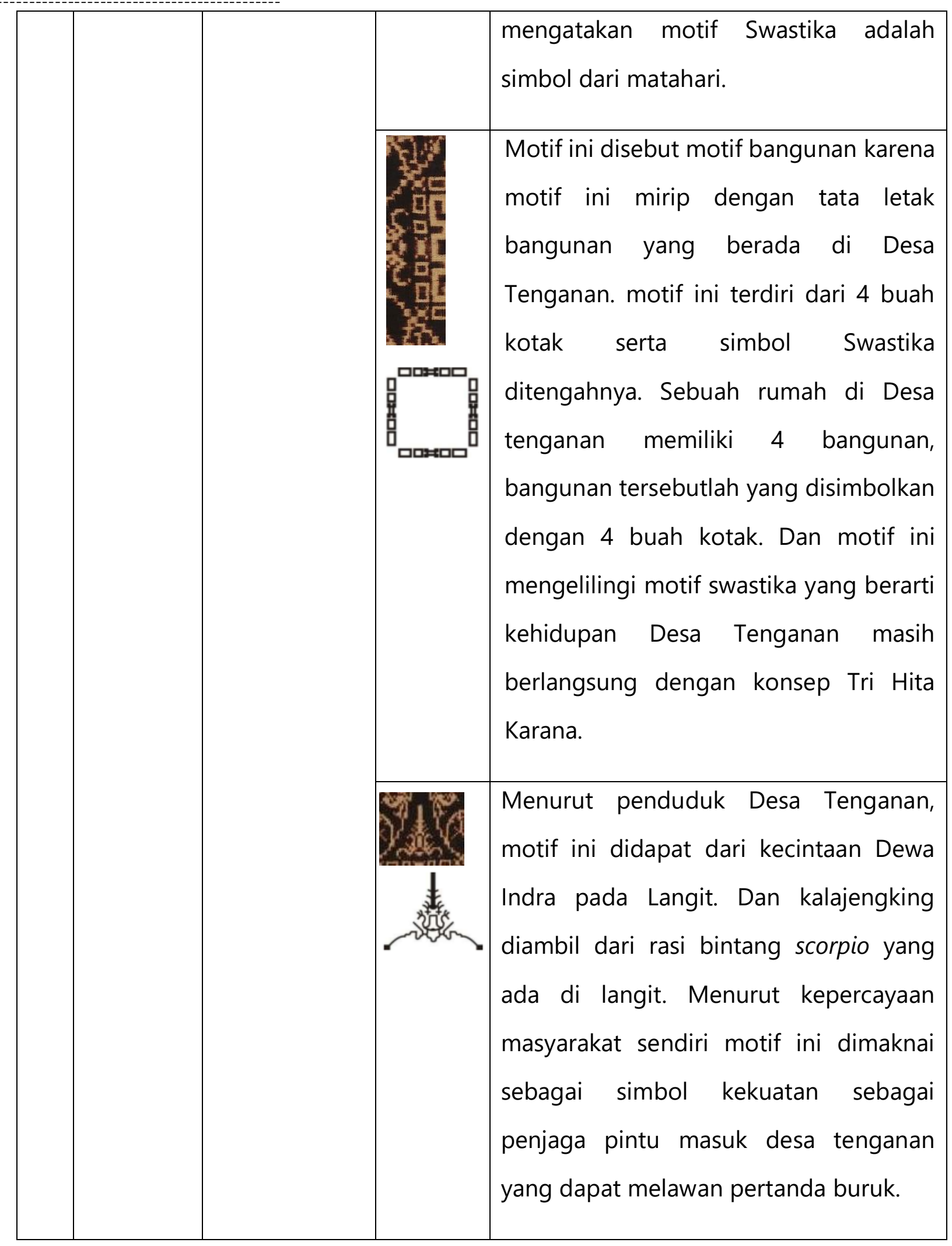




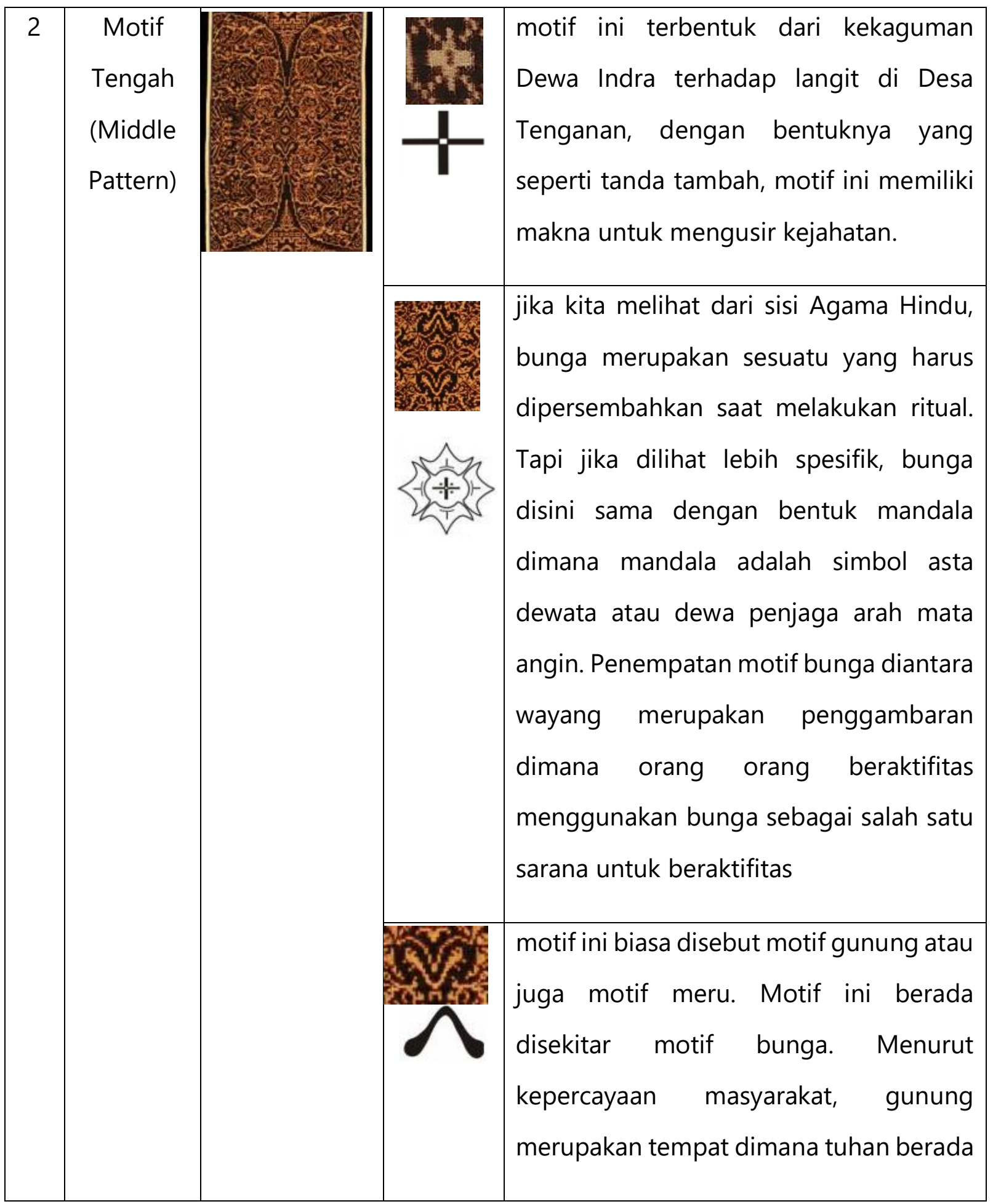




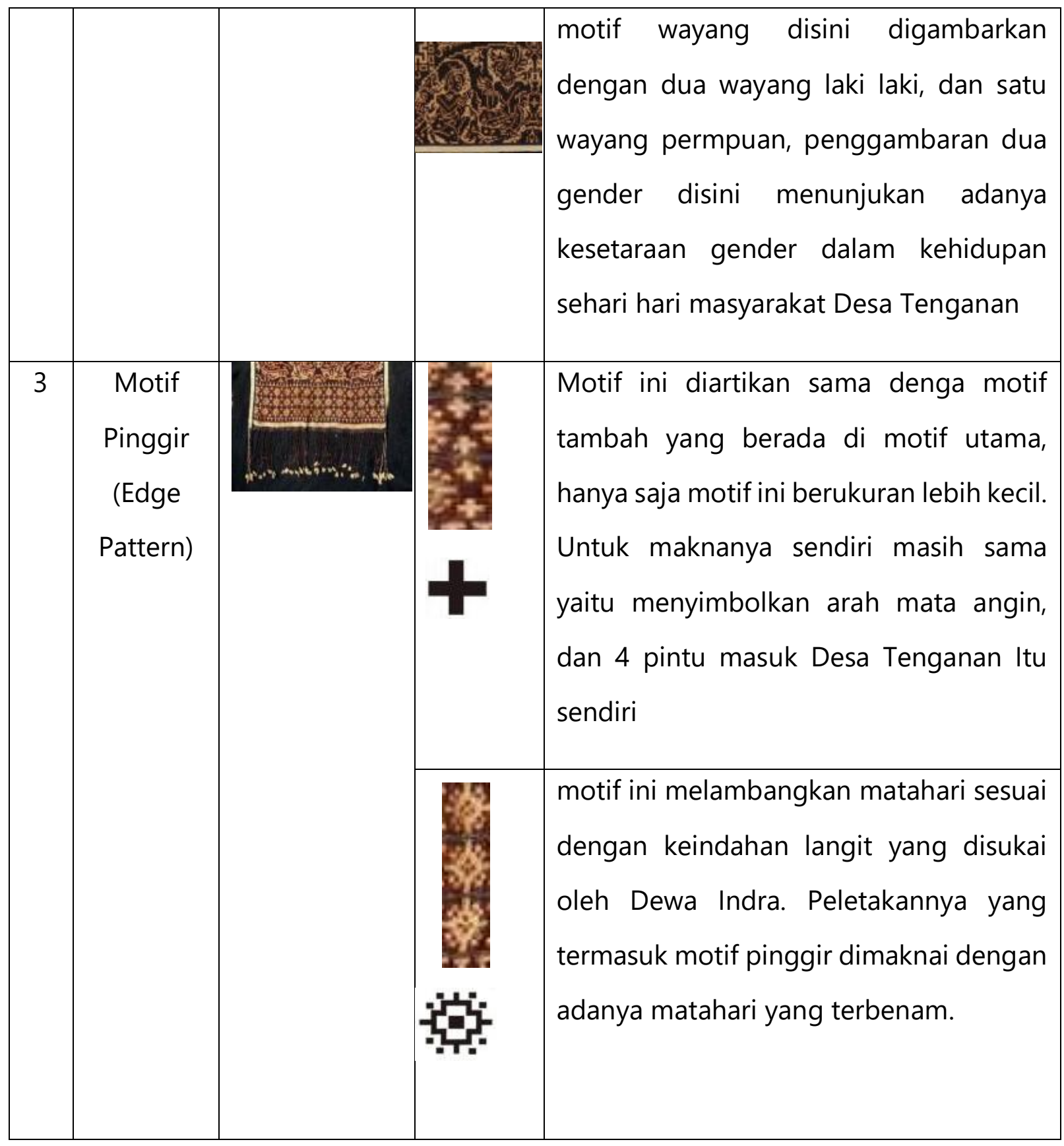

(Sumber : Mudra \& Putriani, 2018)

Kesimpulan : masing masing ornamen dari motif Wayang Kebo pada Tenun Gringsing memiliki arti filosofis mendalam tentang kehidupan penduduk Desa Tenganan Pagringsingan. Ornamen-ornamen 
iini kemudian disusun dalam prinsip visual sesuai dengan pembagian motifnya yang sesuai dengan konsep Tri Mandala pada selembar kain.

a. Eksperimen

Eksperimen ini dilakukan secara digital dengan melakukan stilasi serta mengolah gambar digital dari Tenun Gringsing Wayang Kebo dengan teknik digital imaging. teknik ini merupakan teknik olah gambar digital dengan menggunakan perangkat lunak pengolah gambar vector bitmap seperti Adobe Photoshop diatas sebuah kanvas digital yang diberi nama layer (Kharisma, 2018).

Proses stilasi dengan menggunakan perangkat lunak CorelDraw menghasilkan stilasi bentuk masing-masing ornamen Tenun Gringsing Wayang Kebo.

Proses teknik digital imaging yang menggunakan software Adobe Photoshop dengan teknik potong dan komposisi dari ornamen Tenun Gringsing Wayang Kebo. Tujuan dari proses eksplorasi ini adalah membuat ornamen-ornamen menjadi berbagai macam komposisi dan penggunaan repetisi.

Tabel 3. Eksperimen warna dan potongan ornamen

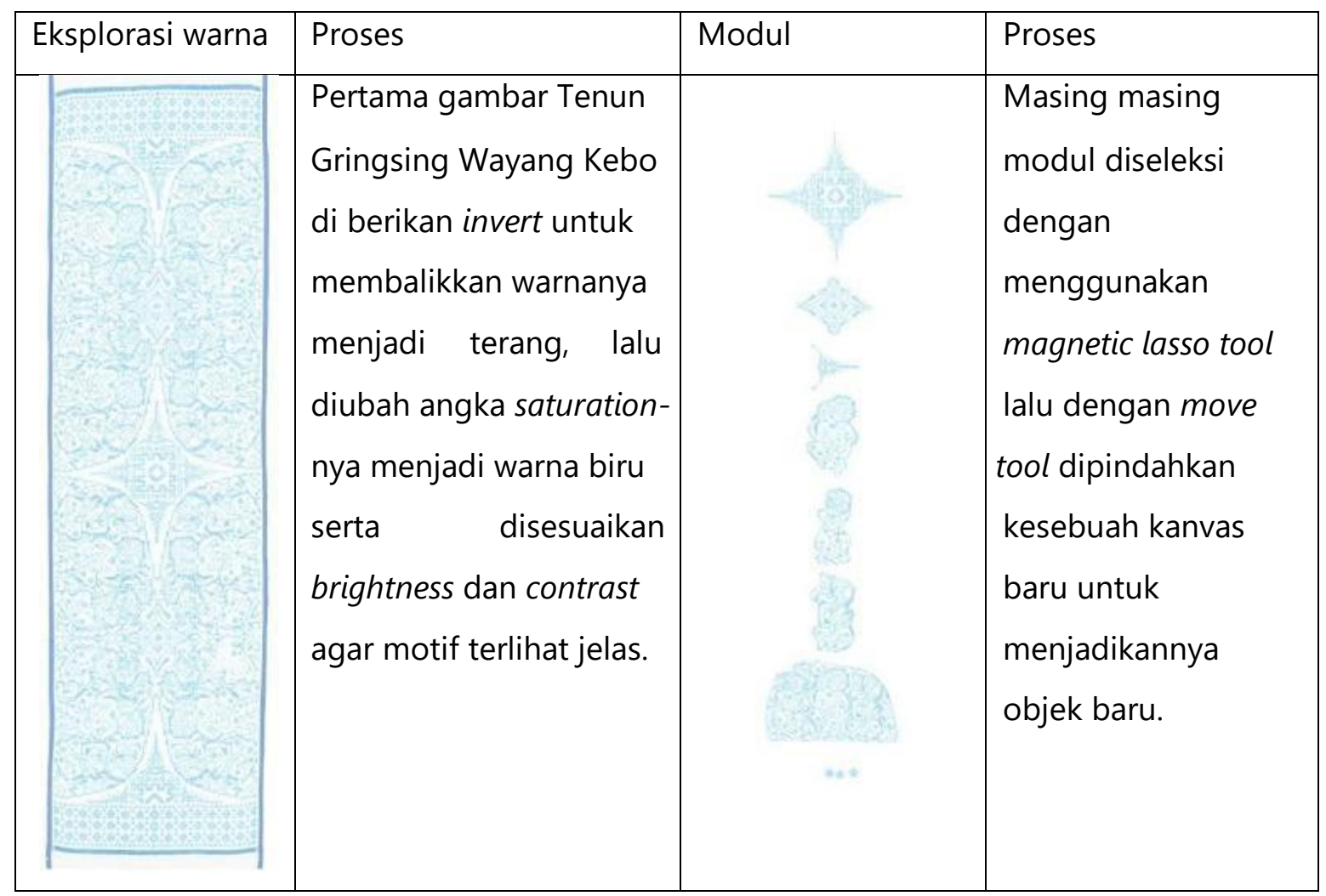




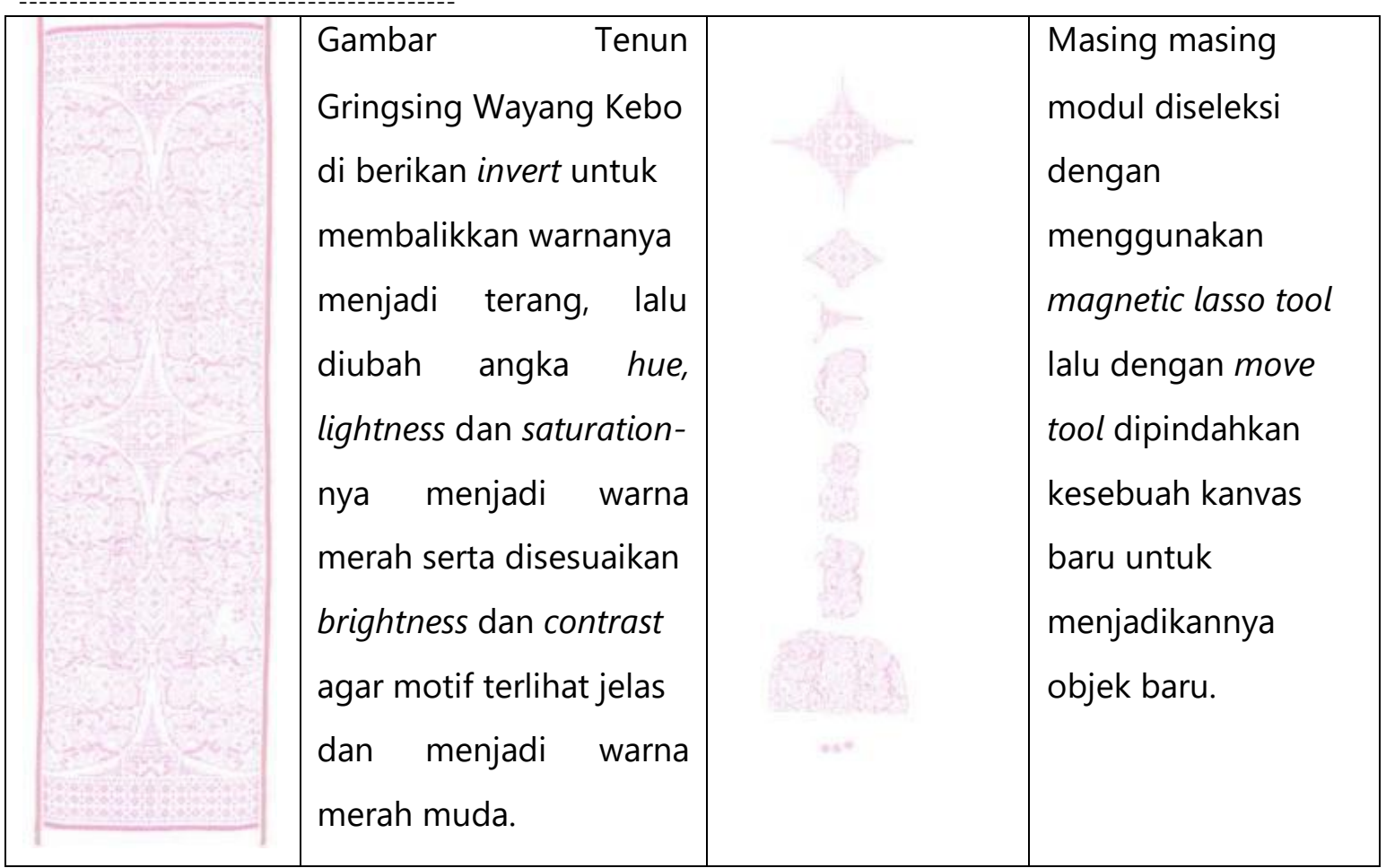

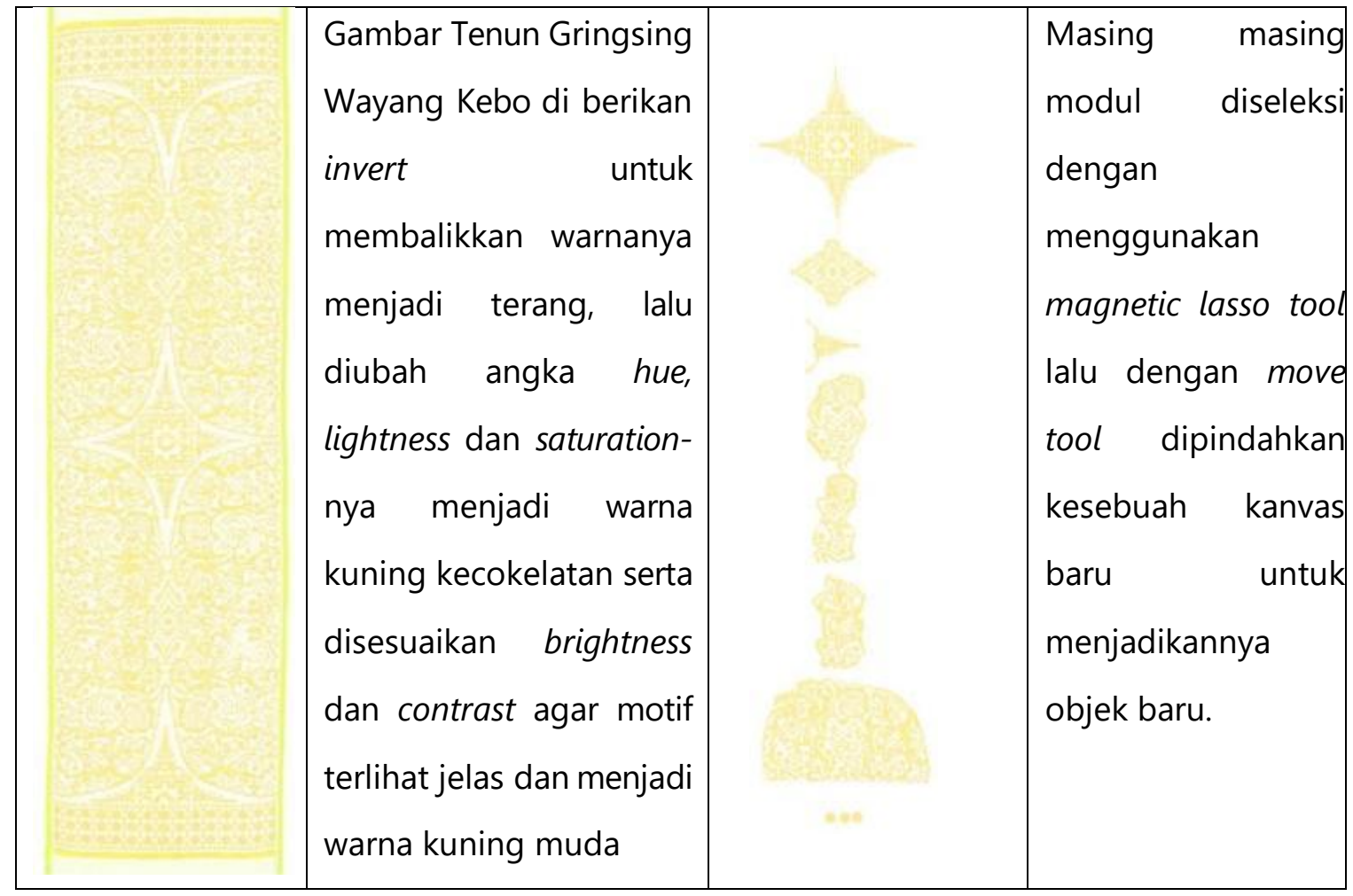




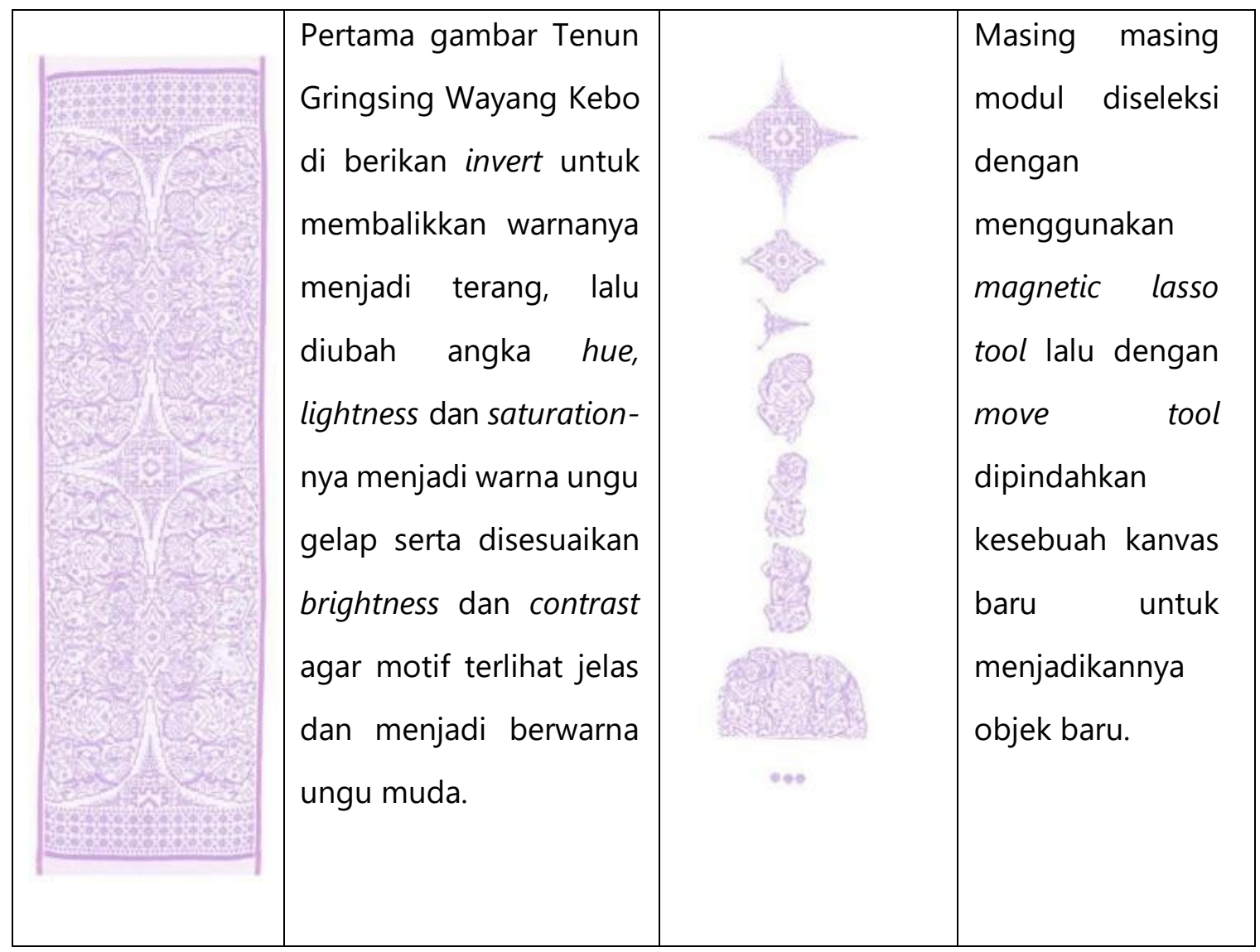

Tabel 4. Tabel eksperimen teknik digital imaging

\begin{tabular}{|l|l|l|}
\hline Modul & Repetisi & Analisis \\
\hline$y$ & & $\begin{array}{l}\text { Modul dari motif ini } \\
\text { terdiri dari ornamen } \\
\text { kalajengking dan } \\
\text { matahari yang disusun } \\
\text { saling membelakangi } \\
\text { dan menggunakan } \\
\text { repetisi half-drop }\end{array}$ \\
\hline
\end{tabular}




\begin{tabular}{|c|c|c|}
\hline 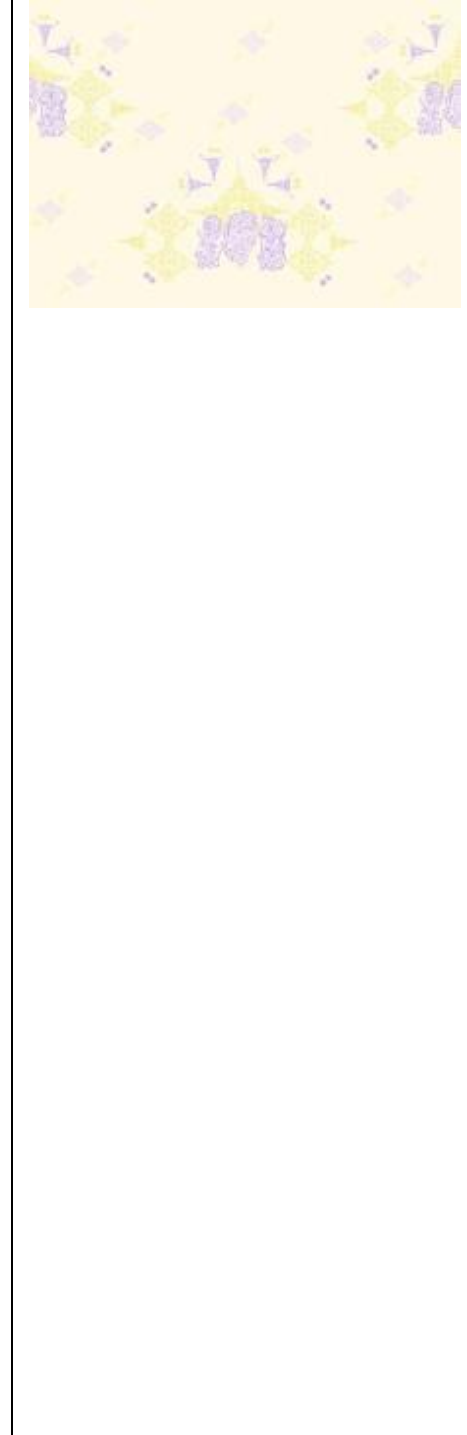 & 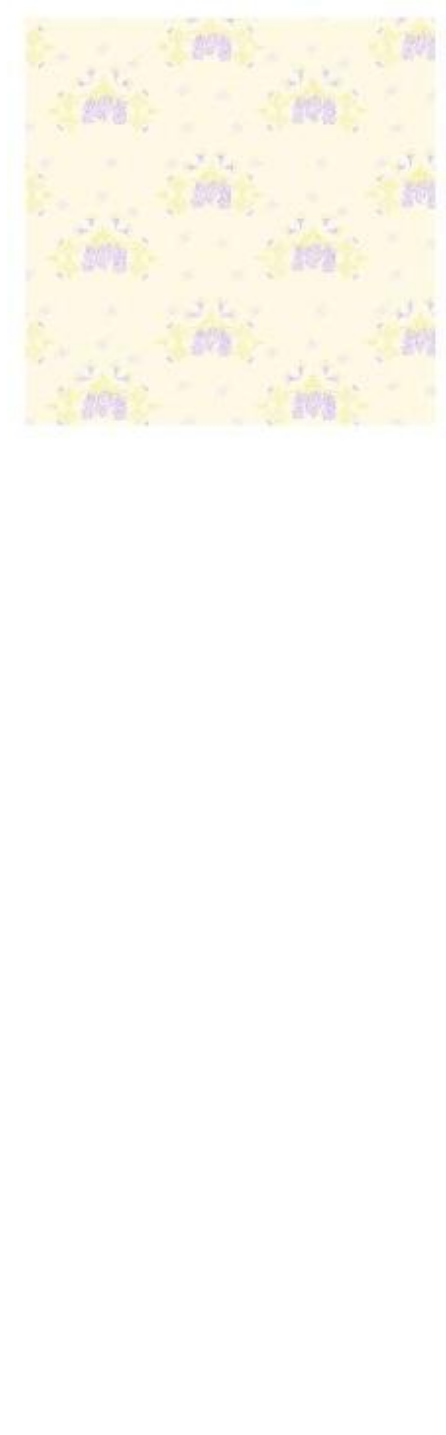 & $\begin{array}{l}\text { Motif ini memiliki dua } \\
\text { buah modul. Satu } \\
\text { modul yaitu modul } \\
\text { utama terdiri dari } \\
\text { gambar wayang sebagai } \\
\text { point of interest yang } \\
\text { dapat dilihat dari } \\
\text { penggunaan warna } \\
\text { yang berbeda serta } \\
\text { ukuran bentuk yang } \\
\text { besar dengan letaknya } \\
\text { yang berada ditengah. } \\
\text { Modul itu juga } \\
\text { mempertahankan } \\
\text { prinsip pencerminan } \\
\text { sehingga bagian kiri } \\
\text { dan kanan kecuali } \\
\text { bagian wayang yang } \\
\text { menjadi point of } \\
\text { interest, terlihat simetris. } \\
\text { Modul kedua yaitu } \\
\text { modul isen isen yang } \\
\text { merupakan transparansi } \\
\text { dari } 3 \text { ornamen yaitu } \\
\text { bentuk motif gunung } \\
\text { dan kalajengking. Motif } \\
\text { kedua ini menggunakan } \\
\text { repetisi brick repeat. }\end{array}$ \\
\hline & 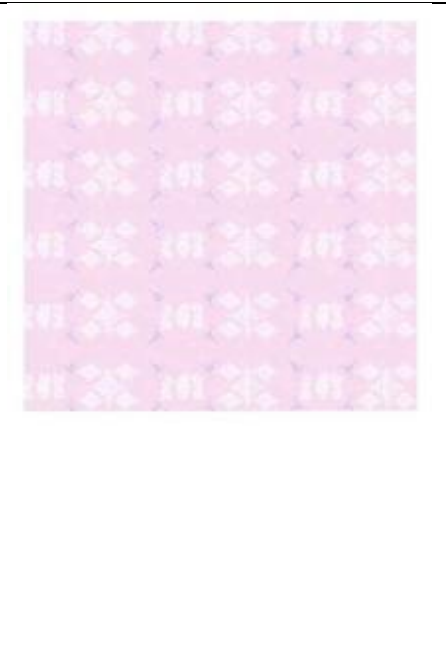 & $\begin{array}{l}\text { Motif ini memiliki } 2 \\
\text { buah motif yaitu motif } \\
\text { utama dan isen-isen. } \\
\text { Isen-isen dalam motif } \\
\text { ini terdiri dari ornamen } \\
\text { matahari dan } \\
\text { kalajengking yang } \\
\text { diletakkan secara acak, } \\
\text { sedangkan motif utama } \\
\text { terdiri dari wayang yang } \\
\text { dikeliling kalajengking } \\
\text { serta bagian main dan } \\
\text { middle pattern Tenun }\end{array}$ \\
\hline
\end{tabular}




\begin{tabular}{|c|c|c|}
\hline & & $\begin{array}{l}\text { Gringsing Wayang Kebo } \\
\text { yang disusun } \\
\text { disebelahnya. } \\
\text { Penyusunan main dan } \\
\text { middle pattern } \\
\text { menggunakan } \\
\text { pencerminan vertikal } \\
\text { dan horizontal sehingga } \\
\text { bagian tersebut terlihat } \\
\text { simetris. }\end{array}$ \\
\hline 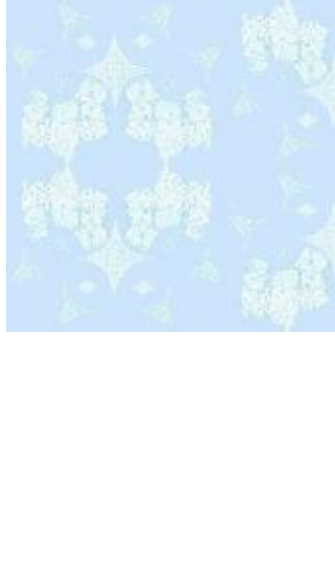 & 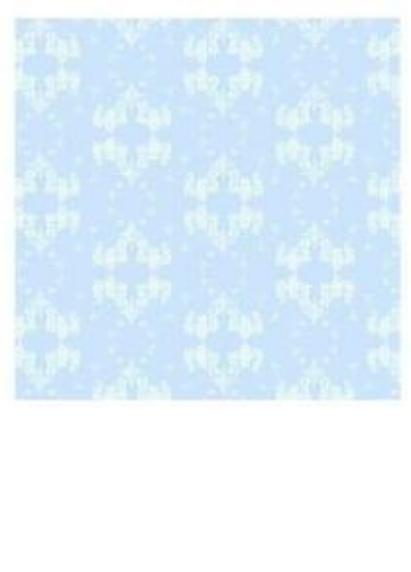 & $\begin{array}{l}\text { Motif ini memiliki satu } \\
\text { buah motif utama } \\
\text { dengan teknik } \\
\text { pengulangan setengah } \\
\text { langkah atau half-drop } \\
\text { repeat. Modul dari motif } \\
\text { ini terbuat dari susunan } \\
\text { bentuk ornamen yang } \\
\text { disusun simetris dengan } \\
\text { pencerminan vertikal } \\
\text { dan horizontal. }\end{array}$ \\
\hline 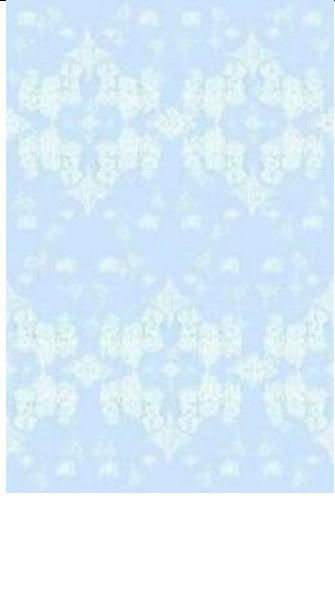 & & $\begin{array}{l}\text { Dengan modul yang } \\
\text { sama motif ini dibuat } \\
\text { dengan hanya memiliki } \\
\text { sebuah modul utama } \\
\text { yang masing masing } \\
\text { ornamennya disusun } \\
\text { dengan menggunakan } \\
\text { pencerminan vertikal } \\
\text { dan horizontal serta } \\
\text { teknik yang digunakan } \\
\text { untuk membuatnya } \\
\text { adalah brick repeat. }\end{array}$ \\
\hline
\end{tabular}




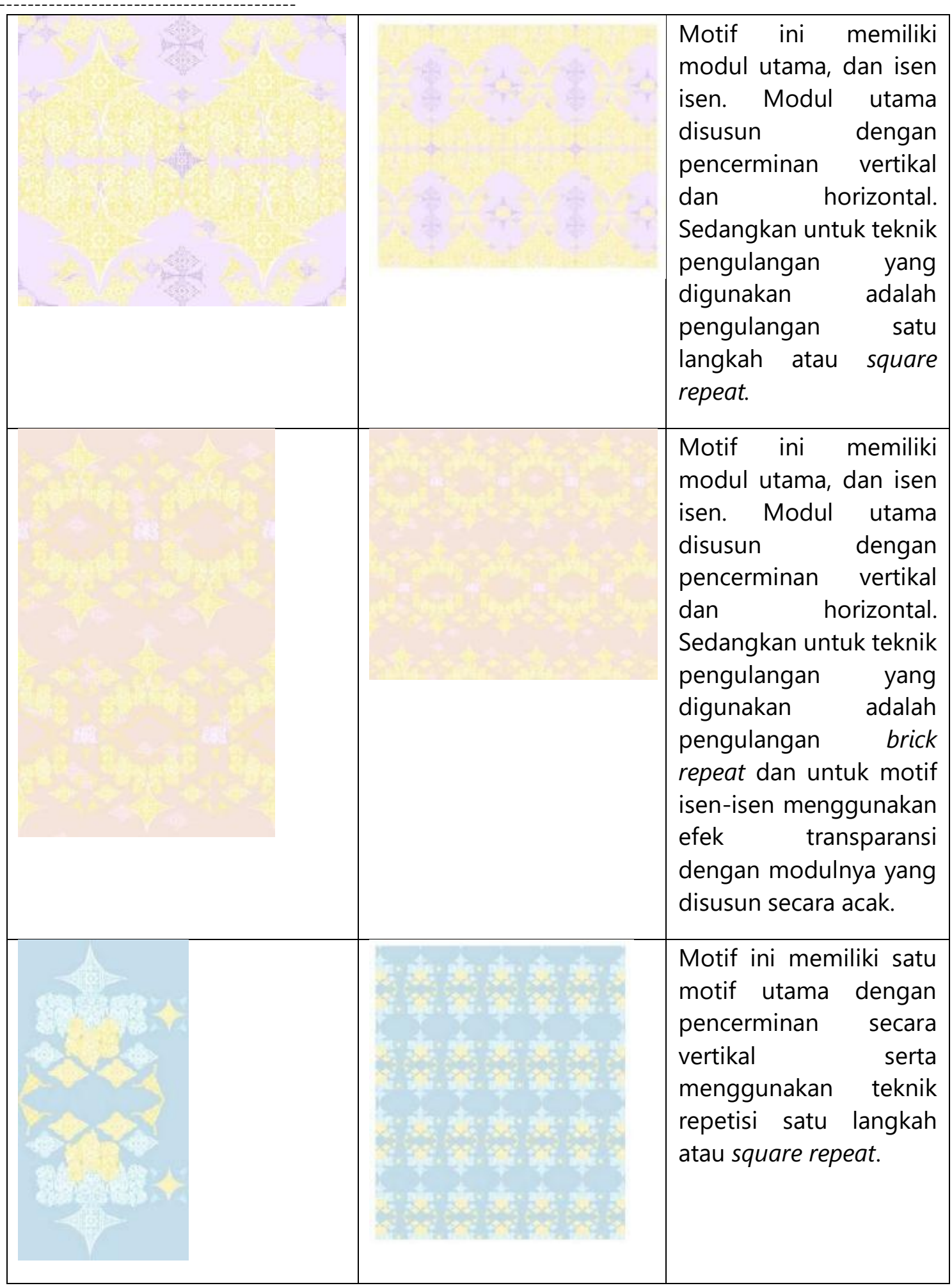




\begin{tabular}{|c|c|c|}
\hline & & $\begin{array}{l}\text { Motif ini terdiri dari } \\
\text { sebuah motif utama dan } \\
\text { isen-isen. Motif utama } \\
\text { dibuat dengan } \\
\text { menggunakan } \\
\text { pencerminan secara } \\
\text { horizontal dan isen-isen } \\
\text { diletakkan secara acak } \\
\text { dengan } \\
\text { transparansi. Teknik } \\
\text { pengulangan yang } \\
\text { digunakan dalam motif } \\
\text { ini adalah teknik brick } \\
\text { repeat. }\end{array}$ \\
\hline & 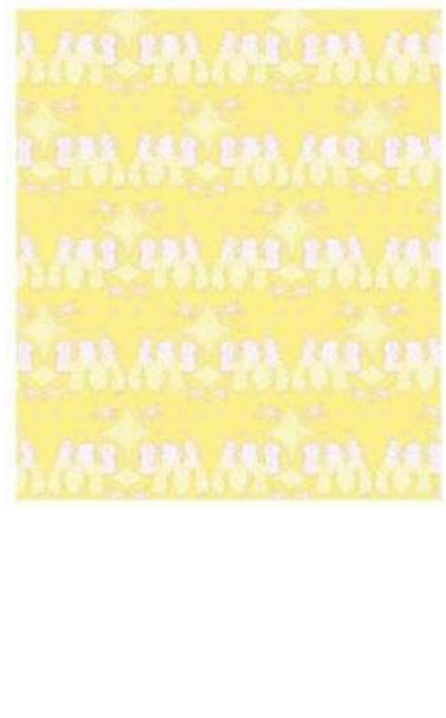 & $\begin{array}{l}\text { Motif ini terdiri dari } \\
\text { sebuah motif utama dan } \\
\text { isen-isen. Motif utama } \\
\text { dibuat dengan } \\
\text { menggunakan } \\
\text { pencerminan secara } \\
\text { horizontal dan isen-isen } \\
\text { diletakkan secara acak } \\
\text { dengan } \\
\text { transparansi. Teknik } \\
\text { pengulangan yang } \\
\text { digunakan dalam motif } \\
\text { ini adalah teknik brick } \\
\text { repeat. }\end{array}$ \\
\hline 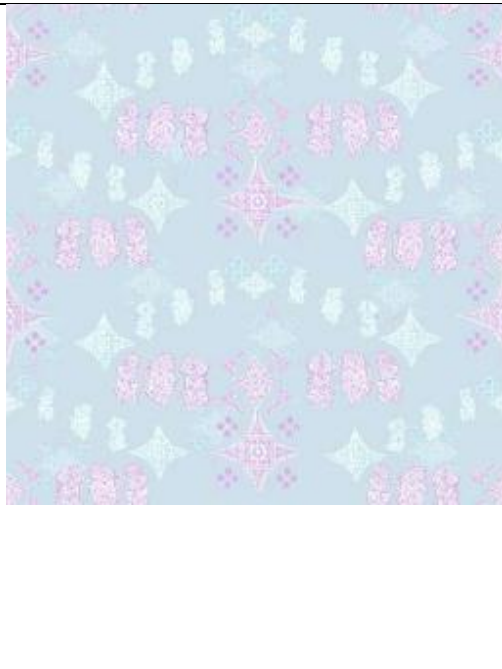 & 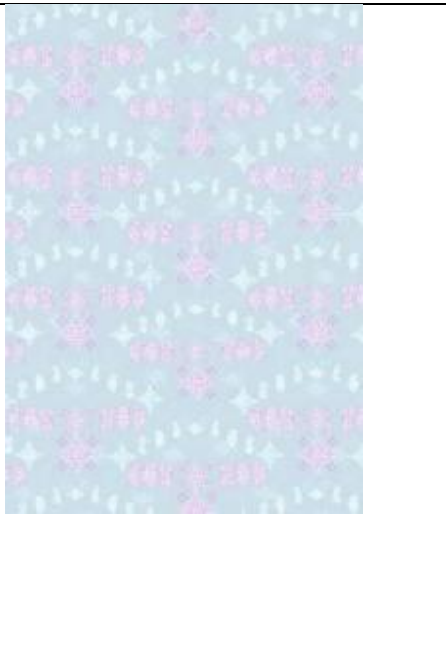 & $\begin{array}{l}\text { Motif ini terdiri satu } \\
\text { motif utama yang } \\
\text { dibuat menggunakan } \\
\text { beberapa bentuk } \\
\text { ornamen yang disusun, } \\
\text { isen-isen yang } \\
\text { diletakkan secara acak } \\
\text { serta menggunakan } \\
\text { efek transparansi dan } \\
\text { menggunakan teknik } \\
\text { repetisi half-drop repeat } \\
\text { atau teknik setengah } \\
\text { Langkah. }\end{array}$ \\
\hline
\end{tabular}

(sumber : Dokumentasi Pribadi, 2020) 
Dari eksporasi yang telah dilakukan didapat hasil motif baru yang bervariasi. Hal ini didapat dari pengkomposisian motif dengan berbagai macam warna dan Teknik repetisi. Selanjutnya motif ini akan dipilih kemudian melalui proses desain untuk dijadikan sebuah produk ready-towear womenswear.

C. Aplikasi pada produk

Dari variasi motif yang sudah didapat, terpilihlah salah satu motif untuk diaplikasikan kedalam produk ready-to-wear womenswear. Dalam produk ini teknik yang digunakan adalah teknik digital printing dimana teknik ini memikili kelebihan dapat dengan mudah diproduksi masal dan tidak memerlukan perawatan khusus dalam pemakaiannya. Perancangan produk ini didasarkan pada pemakaian produk semiformal dengan desain yang longgar dan mudah disesuaikan ukurannya sehingga produk ini dapat disukai.

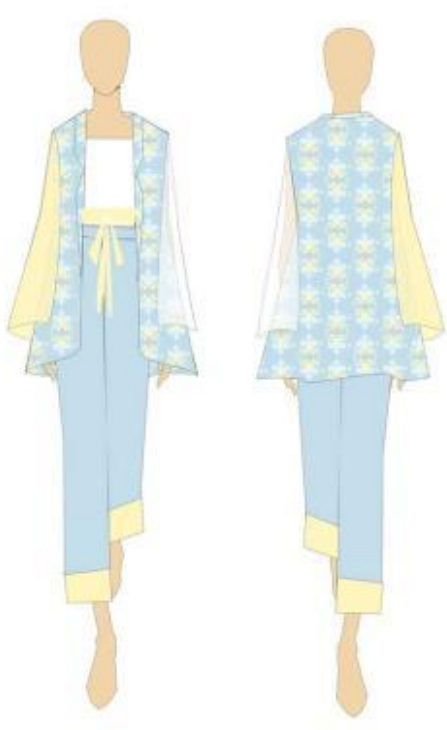

Gambar 1. Sketsa Produk Akhir (sumber: Dokumentasi Pribadi) 


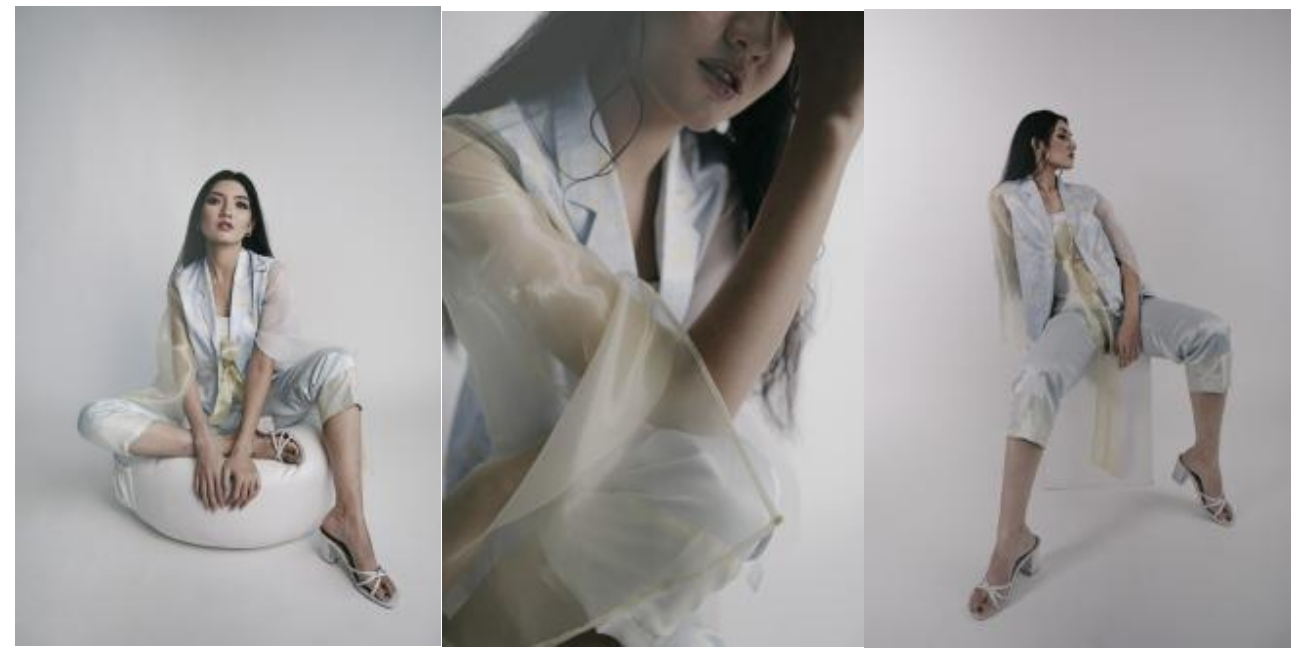

Gambar 2. Foto Produk Akhir

(Sumber : Dokumentasi pribadi)

\section{DISKUSI}

Dari hasil yang sudah dipaparkan diatas, Tenun Gringsing Wayang Kebo yang saat ini sudah jarang ditemukan dapat dijadikan sebagai inspirasi pembuatan variasi motif baru. Pembuatan variasi motif baru tidak akan mengubah arti atau makna filosofis dari motif Wayang Kebo itu sendiri. Karena pada pembuatan variasi motif ini, Motif Wayang Kebo pada Tenun Gringsing hanya dijadikan sebagai inspirasi, tidak mengubah bentuk visual asli. Hal-hal seperti prinsip visual dan beberapa bentuk ornamen pada motif Wayang Kebo inilah yang dijadikan sebagai inspirasi pengkomposisian variasi motif baru yang leboh moderen.

\section{PENUTUP}

Kain Tenun Gringsing Wayang Kebo merupakan wastra yang visualnya memiliki makna yang dalam bagi masyarakat desa tersebut. Dari visualnya yang menjadi salah satu daya tarik dari kain ini, maka terlihat adanya potensi untuk dilakukan pengembangan variasi motif yang terispirasi dari kain ini. Teknik digital imaging adalah teknik yang menggunakan gambar digital atau foto dari Tenun Gringsing Wayang Kebo yang diolah seperti memotong dan mengubah warna sehingga bentuk visual motif aslinya masih bisa terlihat. Teknik ini dapat menghasilkan motif bervariasi seperti motif dengan pengulangan satu langkah, setengah langkah hingga brick repeat 
serta motif yang memiliki unsur transparansi dan mudah untuk dikomposisikan asimetris maupun simetris hingga memiliki warna beragam karena warna ini dapat disesuaikan sesuai keinginan dengan penggunaan warna digital.

Pengaplikasian variasi motif yang terinspirasi dari Kain Tenun Gringsing Wayang Kebo kedalam produk womenswear dilakukan dengan teknik digital printing. Hal ini dilakukan karena variasi motif yang diolah secara digital menggunakan setting atau pengaturan warna yang cocok secara digital sehingga digital printing akan mempermudah pengaplikasian pada kain dan dapat diproduksi dalam warna beragam dan masal. Pengaplikasian pada produk dimulai dari pencetakan motif pada kain kemudian pembuatan desain produk yang menggunakan motif yang sudah dicetak, kemudian tekstil bermotif akan memulai proses jahit. Kemudahan aftercare, keberagaman warna, kemudahan produksi masal dari teknik ini membuat teknik ini cocok untuk digunakan untuk womenswear ready-to-wear.

\section{DAFTAR PUSTAKA}

Salain, M. S. P. D. Perlindungan Hukum Terhadap Kebudayaan Bali Sebagai Sumber Daya Ekonomi Pariwisata. Kertha patrika, 39(01), 01-15.

Kartiwa, Suwati (2007) Ragam Kain Tradisional Indonesia Tenun Ikat, Jakarta,Gramedia Penerbit Utama

Lodra, I Nyoman. (2015). Dibalik Kain Tenun Gringsing. Pramita

Mudra, I. W., \& Putriani, N. E. (2018). Interpreting the Tri Mandala Concept on the Motif of Gringsing Wayang Kebo Woven Cloth. Lekesan: Interdiciplinary Journalof Asia Pasifc Arts, 1(1Page), 30-38.

Kharisma, B. Z. S. (2018). Tokoh Pandawa Sebagai Ide Dasar Penciptaan Karya Seni Lukis Dengan Menggunakan Teknik Digital Imaging.

Widiawati, D., Sn, S., Sn, M., Rosandini, M., \& Ds, S. (2012). Natural Dyes on Indonesian Traditional Textiles - A Case Study: Geringsing Woven Fabric, In Tenganan Pegeringsingan Village Bali -. 복식문화학회지:복식문화연구, 20(1), 111-120.

Andini, D. R., \& Rosandini, M. (2018). Pengolahan Motif Dari Inspirasi Ornamen Tamansari Keraton Yogyakarta. ATRAT: Jurnal Seni Rupa, 5(3). 
